\title{
ЭКСПРЕССИВНАЯ ФУНКЦИЯ ПРЕФИКСАЛЬНОЙ МОРФЕМЫ В РОМАНЕ А.С. ПУШКИНА ЕВГЕНИЙ ОНЕГИН
}

\author{
EXPRESSIVE FUNCTION OF THE PREFIXAL MORPHEME \\ IN ALEXANDER PUSHKIN'S EUGENE ONEGIN
}

\author{
СВЕТЛАНА ГОРБУНОВА
}

\begin{abstract}
The article is devoted to studying word-building as a means of achieving expression in Pushkin's Eugene Onegin; particular attention is given to the prefixal morpheme. As for the fact that the novel was written in verse, the author analyzes the processes associated with implementing the poetic function of language.
\end{abstract}

Светлана Горбунова, Казанский федеральный университет, Казань - Россия.

На современном этапе развития лингвистики вопросы анализа языка поэзии с точки зрения реализации словообразовательных возможностей разработаны крайне слабо.

Начало исследований морфем как средства выразительности связано с именами Л.В. Щербы, назвавшего эстетически обусловленное использование аффиксов „грамматикой поэзии"1, и Р. Якобсона, считавшего, что „поэтичность - это не просто дополнение речи риторическими украшениями, а общая переоценка речи и всех ее компонентов", в том числе и элементов словопроизводства ${ }^{2}$. Художественным приемам посвящена статья Е.А. Земской, где на материале текстов публицистики, поэзии и прозы показан статус морфемы как экспрессивно-стилистического средства ${ }^{3}$.

Среди работ, изучающих роль морфем в творчестве отдельных писателей, выделяется исследование Л.В. Зубовой, в котором рассматривается специфика организации поэтических произведений М. Цветаевой и уделяется особое внимание внутренней форме лексемы, то есть „характеру связи звукового состава слова и его первоначального значения" ${ }^{4}$. К изучению новообразований в современной поэзии обраща-

1 Л.В. Щ е р б а, Избранные работы по русскому языку, Москва 1957.

2 Р. Я к о б с о н, Лингвистика и поэтика, Москва 1975.

${ }^{3}$ Е.А. 3 е м с к а я, Словообразовательные морфемы как средство художественной выразительности, „Русский язык в школе” 1965, № 3.

4 Л.В. 3 у б о в а, Язык поэзии Марины Цветаевой (фонетика, словообразование, фразеология), Санкт-Петербург 1999. 
ется М.А. Бакина, делая акцент на их эстетической функции и степени новизны, которая, по мнению автора, зависит от продуктивности словообразовательного типа 5 .

Однако до сих пор не создано исчерпывающей картины экспрессивной значимости словообразовательной морфемы.

Неизученными в данном аспекте остаются и произведения выдающихся писателей и поэтов, в частности Евгений Онегин А.С. Пушкина, мастерски использующего средства словообразования для создания художественной выразительности.

Наибольшую экспрессивность в тексте романа в стихах проявляют префиксальные морфемы, которые нередко несут бо́льшую семантическую нагрузку, чем основы, позволяют выявить потенциальные возможности лексем, показать динамичный характер языковых элементов на словообразовательном уровне.

Одним из наиболее часто используемых приемов является повтор nрефикса. Например, многократно используя приставку не-, имеющую значение „отсутствие признака”, А.С. Пушкин создает необыкновенно насыщенные, яркие образы. Таково описание „причудниц большого света" - дам высшего общества: „Но вообще их разговор//Несносный, хоть невинный вздор;//К тому ж они так непорочны, //Так величавы, так умны,// [...] Так неприступны для мужчин,//Что вид их уж рождает сплин"6.

Обращает на себя внимание тот факт, что в контексте противопоставлены прилагательные с одинаковой приставкой: несносный и неbuнный. Подчеркнем, что на современном этапе невинный мотивируется лексемой $\boldsymbol{b u н a}$ и является конфиксальным образованием. Однако А.С. Пушкин реставрирует древнее слово винный (адъектив от существительного „вина"), зафиксированное с XII века в Словаре русского языка XI-XVII Bb. со значением 'виновный, виноватый'7. Возникает словообразовательная цепь: Вина > винный > невинный. Таким образом, посредством реэтимологизации поэт возобновляет исконные связи между словами. Наличие единого префикса ставит специфические смысловые акценты на лексемах невинный и несносный, являющихся в узуальном языке нейтральными, в результате чего они вступают в антитезные отношения: описание интересов светских дам становится предельно негативным, их разговоры пусты и не представляют никакого интереса.

В этот ряд включаются также краткие адъективные образования непорочны (от непорочныи < порочный) и неприступны. Последнее, как и рассмотренное невинный, в современном русском языке соотносится

5 М.А. Б а к и н а, Новообразования в современной поэзии, „Русская речь” 1975, № 2.

6 Все цитаты по изданию: А.С. П у ш к и н, Евгений Онегин. Собрание сочинений в десяти томах, т. 4, Москва 1959, с. 5-190.

${ }^{7}$ Словарь русского языка XI-XVII въ., вып. 2, Москва 1975-2004, с. 181-182. 
с существительным пристуn, и в его структуре выделяется конфикс не...н, однако допушкинской эпохе известно прилагательное пристуnный: в одном из значений - 'досягаемый, доступный'8 - оно и явилось производящим для использованного поэтом слова. Употребление кратких форм наделяет рассматриваемые адъективы предикативностью и дополнительной глагольной семантикой.

В целом последовательность подобных прилагательных, завершающаяся словом непорочны, должна создать, казалось бы, возвышенный образ благочестивых дам, однако пушкинская ирония меняет картину: „невинным” оказывается вздор, а вид непорочных и неприступных „причудниц” лишь „рождает сплин", вызывает тоску. Таким образом, автор рисует в высшей степени иронический портрет светского общества при помощи нескольких ярких штрихов, которыми являются прилагательные с префиксом не-.

Примечательно, что в ЕВгении Онегине перечни подобных однородных прилагательных нередко связаны с изображением внешности и манер поведения женщин. Таково, например, рассуждение повествователя об умении дам изъясняться на родном языке: „Неправильный, небрежный лепет,//Неточный выговор речей//По-прежнему сердечный треnет//Произведут в груди моей". Перед нами вновь пример иронии, но куда более мягкой, чем в предыдущем случае. Адъективы с приставкой не- создают не отталкивающий образ холодной пустоты, а скорее подчеркивают беспомощность барышень в попытках говорить по-русски, что вызывает умиление говорящего и насмешку автора.

В контексте выступают синонимы: неправильный и неточный, причем второе прилагательное приобретает дополнительное значение 'не соответствующий правилам родного языка', являющееся основным для первого. Атрибутив небрежный вновь демонстрирует стремление автора вскрыть глубинные отношения между словами: будучи нечленимым в современности, у А.С. Пушкина он мотивируется древним прилагательным брежный - 'сохранный, хранимый', неполногласным стилистическим синонимом адъектива бережный, зафиксированным Словарем русского языка XI-XVII вb. ${ }^{9}$

Заслуживают внимания контексты, в которых объединены слова с родственными основами, осложненными антонимичными префиксами или звуковыми комплексами, претендующими на статус морфемы, способной объединить лексемы и структурно, и семантически. Эффекты, достигаемые при помощи указанного приема, варьируются от предельного комизма до глубочайшего драматизма: „Изображу ^ь

8 Там же, вып. 20, с. 41.

9 Там же, вып. 1, с. 331. 
В картине верной//Уединенный кабинет,//Где мод воспитанник примерный //Одет, раздет и вновь одет?".

Отметим, что представленный пример - один из наиболее „прозрачных" в плане соотнесенности между словами, осложненными антоморфемами. В данном случае мы действительно имеем дело с лексемами, связанными непосредственными словообразовательными отношениями, статус префиксов также не вызывает сомнений: перед нами именно приставки, имеющие противоположные значения. Этимологический словарь М. Фасмера фиксирует форму детый как страдательное причастие прошедшего времени от славянского глагола $\partial e m \mathbf{b}^{10}$, в данном случае словообразовательная цепь выглядит следующим образом: деть > одеть > одетый (одет), либо, если учесть возможность двойной мотивации, - деть > детый > одетый (одет). Аналогично образована лексема с префиксом раз-. В узусе функционирует глагол деть (МАС маркирует его как разговорный) - ‘положить, засунуть куда-либо, так что трудно найти'11, имевший в языке прошлых эпох куда более широкое значение 'поместить куда-либо' 12 . На современном этапе соотнесенность утрачена, в словах одетый и раздетый отмечаются связанные основы. Сопоставление лексем в поэтической речи - еще один из способов регенерации этимологических связей, используемых А.С. Пушкиным.

Чередование в рамках одной синтагмы кратких причастий, имеющих единую мотивацию и осложненных антонимичными префиксами, создает почти кинематографический эффект быстрой смены кадров, где убранство кабинета составляет статичную декорацию, в которой практически мгновенно происходит изменение внешнего вида героя. Внимание сосредоточено только на факте перехода Евгения из одного состояния в другое, то есть на переодевании как таковом. В данной ситуации автора не интересуют детали костюма героя, ему важно показать совсем иное - обстановку в кабинете. Статичная картинка выдвигается на первый план, и поэтому действия персонажа обрисованы крайне схематично: весь процесс смены костюма сведен к трем глагольным формам (oдеm, раздет, одет). Однако сама по себе подобная концентрация родственных лексем не может не привлечь внимания читателя, и в этом смысле мы можем говорить о таком свойстве поэтического языка А.С. Пушкина, которое можно назвать полиакиентностью: автор способен одновременно удерживать в поле своего зре-

${ }^{10}$ М. Ф а с м е р, Этимологический словарь русского языка: $b$ 4- $x$ т., пер. с нем. О.Н. Трубачев, 2-е изд., стереотип., т. 1, Москва 1986-1987, с. 356.

11 Словарь русского языка: $b$ 4-x т., под ред. А.П. Евгеньевой, 2-е изд., испр. и доп., т. 1, Москва 1981-1984, с. 320.

12 Cловарь русского языка XI-XVII въ., указ. соч., вып. 4, с. 237. 
ния и освещать несколько разнопорядковых явлений или предметов, используя лингвистические средства для того, чтобы с их помощью расставлять необходимые смысловые ударения. При этом поэт экономично использует непосредственно лексические средства: специфика романа в стихах, сохраняющего жесткость лаконичной строфики, не подразумевает излишне многословных отступлений.

Возвращаясь к особенностям проявления экспрессии посредством префиксов, осложняющих родственные основы, приведем другой пример: "Привычкой жизни избалован,//Одним на время очарован,//Разочарованный другим,//[...] Вот как убил он восемь лет". В данном контексте, как и в предыдущем, сталкиваются две однокоренные формы, противопоставленные друг другу при помощи приставок $\boldsymbol{o}$ - и раз(o)-. Антонимичность лексем поддержана на уровне синтаксиса, а именно сочетаемости: причастия управляют творительным падежом местоимений, приобретающих семантику неопределенности: для того чтобы показать прошлую жизнь героя, как время, проведенное впустую, поэт использует местоимения одним, другим, обладающие предельно обобщенным значением, то есть не конкретизирует, чем именно был очарован или разочарован герой.

Нередко в тексте Евгения Онегина противопоставленными оказываются префиксальные производные одной и той же основы, не имеющие антонимической семантики в узуальном языке: „Мои богини! что вы? где вы? //Внемлите мой печальный глас: //Все те же ль вы? другие ль девы,//Сменив, не заменили вас?".

Сменить и заменить в узусе являются синонимами в значении 'появиться, прийти на смену кому-либо или чему-либо'13. Однако А.С. Пушкин, благодаря своей языковой интуиции, подчеркивает тот оттенок значения, которой присущ исключительно лексеме с приставкой за-: 'занять место кого-либо, став равноценным ему'. В результате соположенные в тексте лексемы обретают статус антонимичных. В связи с этим стоит отметить такое свойство языка А.С. Пушкина, как тяготение к афористичности - стремление выразить мысль в предельно яркой и краткой форме.

Префиксальные образования нередко становятся базой для иингвистической игры. Пушкинская игровая техника письма постоянно продуцирует смелые и остроумные каламбуры: „Руссо (замечу мимоходом) //Не мог понять, как важный Грим//Смел чистить ногти перед ним // [...] Защитник вольности и прав//В сем случае совсем неправ". Рифмующиеся омоформы, одна из которых осложнена отрицательным пре-

13 Словарь русского языка: $b$ 4-x m., под ред. А.П. Евгеньевой, указ. соч., т. 1, с. 560, т. 2, с. 492. 
фиксом не-, перекликаясь, создают своеобразный эффект отраженной иронии: поэт вызывает к жизни исконное этимологическое родство слов, при этом противопоставляя их структурно и синтаксически. Усиление эффекта каламбура происходит не только за счет рифмовки, но и благодаря тому, что два последних стиха являют собой завершение строфы.

Таким образом, префиксы как средство достижения экспрессии играют важную роль в тексте ЕВгения Онегина. Употребление тех или иных приставочных новообразований способно стать основой самостоятельного приема организации художественного произведения, который может быть основан на повторе единиц, их противопоставлении и взаимодействии, а также на определенной стилистической маркированности. Приставка может быть носителем субъективного авторского смысла, заставляя лексему принимать новое, окказиональное значение. Нередко префиксальные производные выступают в качестве структурообразующего звена, оттесняя на второй план семантику производящей основы. В связи с этим возникает та удивительная игра с читателем, участниками которой мы становимся. В ее арсенале - богатство семантических трансформаций, реэтимологизация, коннотации и особенности поэтического синтаксиса. Именно умение задействовать все пласты языка в их тесной взаимосвязи отличает стиль А.С. Пушкина и создает необычайную структуру повествования Евгения Онегина. 